\title{
The Affecting Factors of Commitment to Change after Reorganization in PT PLN (Persero) UIP Sumbagut
}

\author{
Ratih Sri Handayani ${ }^{1}$, Isfenti Sadalia ${ }^{2}$, Rulianda Purnomo Wibowo ${ }^{2}$ \\ ${ }^{1,2}$ Master of Management on Postgraduate School of University of Sumatera Utara
}

Corresponding Author: Ratih Sri Handayani

\begin{abstract}
Organizational change is directed at increasing the effectiveness and improvement of organizational capabilities. PT PLN (Persero) where one of its units is PLN UIP Sumbagut reorganized in 2018 which included several business functions. The purpose of this study is to understand the factors that affect employee commitment to change after reorganization, namely through trust, emotional attachment and perceived organizational support. The data processing method in this study is to use the causality method between variables with the Structural Equation Modeling (SEM) Partial Least Square (PLS) modeling equation. The measurement results showed that the Trust variable (X1) was $0,4 \%$ \& insignificant with a p-value of $0,637>0,05$, the Emotional Attachment (X2) variable was $86 \%$ \& significant with a p-value of $0,016<0,05$ and Perceived Organizational Support (X3) of $14,3 \%$ \& significant with a a p-value of $0,000<0,05$ is able to directly influence Employee Commitment to Change as part of an indicator of organizational climate which is very inherent in determining organizational success. The results of the evaluation show that in an effort to build a commitment to change, management needs to increase the intensity of communication among employees both formally and informally to improve the harmony of relationships between colleagues, the generation gap can be managed specifically with a relationship-oriented approach, namely by placing between generations in one work team. To increase trust, increase employee engagement through networking programs through work networking on work experience
\end{abstract}

and the use of technology, increased organizational support that is felt can be done by cerating a work system that is supported by media aspirations of employees that area evaluated regularly, empowering employees to be more active in implementing changes and conduct special training proactively.

Keywords: Reorganization, Trust, Emotional Attacment, Perceived Organizational Support, Employee Commitment to Change

\section{BACKGROUND}

PT PLN (Persero) the Northern Sumatera Development Main Unit, also known as PLN UIP Sumbagut, is a unit in charge of handling the construction of transmissions and substations in the Northern Sumatera region. The policy change made by PLN UIP Sumbagut is to strengthen business functions and customer service by optimizing the development of strategic projects in accordance with the RUPTL. Strengthening the function of asset \& legal management by increasing awareness and consistency in the implementation of $\mathrm{K} 3$, resolution of certification, land disputes and others. Strengthening the compliance function by improving the evaluation and analysis of the impact of fraud and internalizing a compliance culture. Also strengthening the $\mathrm{HR}$ function with routine $\mathrm{CoC}$ (Code of Conduct) activities to improve industrial relations in understanding corporate strategic needs, internalizing the Best PLN values to support HR with integrity and 
others. In carrying out its duties and functions, PLN UIP Sumbagut relies on the capabilities and expertise of competent and highly dedicated people. Differences in the perceptions or mindsets of these individuals trigger resistance factors that affect the group to impact the resistance to change in the organization. Some employees still feel that they do not believe that change can lead to continuous improvement and incompatibility in implementing changes so that this makes PLN UIP Sumbagut employees low commitment to change. In addition, in adapting to organizational change, there is often a gap between generations in responding to it. Due to the current organizational changes occurring are matched by an increase in new programs and technological developments in the implementation of work.

To see the existing phenomena related to organizational change, a presurvey was conducted with 20 employees of the PLN UIP Sumbagut to describe the condition of resistance in the organization. The results of the pre-survey showed that 14 employees with a score of $50 \%$ felt that they were unable to complete the new assignments given because of limited knowledge and information about the new assignments given. This is because employees feel that they have limited knowledge and information about new assignments. There are 11 employees with a score of $57 \%$ feel that they cannot control their own work, so they feel they are not able to take part and increase creativity in their own work. There are 18 employees with a score of $38 \%$ feel that the main reason that underlies them in following changes is because the company is not from the employees themselves. From within, employees themselves do not have the ability to keep up with changes. There are 10 employees with a score of $58 \%$ feel they do not have an internal need to make changes in the company. As many as 15 employees with a score of $46 \%$ stated that employees felt ineffective in doing work after a change, such as employees being confused and having to adjust to new tasks and job descriptions. On the other hand, superiors ask to finish their work quickly, causing less productive performance. Then, 17 employees with a score of $40 \%$ stated that the company had not fully provided supporting training to deal with change.

Past research has shown that commitment plays an important role in shifting from resistance to readiness for change. Commitment as a significant predictor of change resistance also highlights the emotional attachment of employees that is formed as a factor that contributes to a more positive intention to support change and is oriented towards changing behavior for the benefit of the company. The commitment of employees to change also tends to show an indication of confidence that change is supported by the organization that will benefit all stakeholders. Resistance needs to be managed with preventive actions with the right schemes, strategies and corporate actions.

\section{Reorganizational}

Reorganizational is a process by which the organization moves from its present state to the desired future to increase its organizational effectiveness. The aim is to find new or improved ways to use resources and capabilities with the aim of increasing the organization's ability to create value and increase the desired results to stakeholders.

\section{Commitment to Change}

Holt, et al (2007) states an individual's readiness to change as a comprehensive attitude that is simultaneously influenced by content (what changes), process (how change is implemented), context (the environment in which change occurs), and individual (individual characteristics that are asked to change) that involved in a reorganization. When the organizational commitment to change is high, members of the organization will be more interested in initiating / 
initiating change, exerting greater effort for the change, showing greater persistence, and displaying more cooperative behavior towards change which will ultimately help the effectiveness / success of implementing change. (Weiner, 2009).

\section{Conceptual Framework}

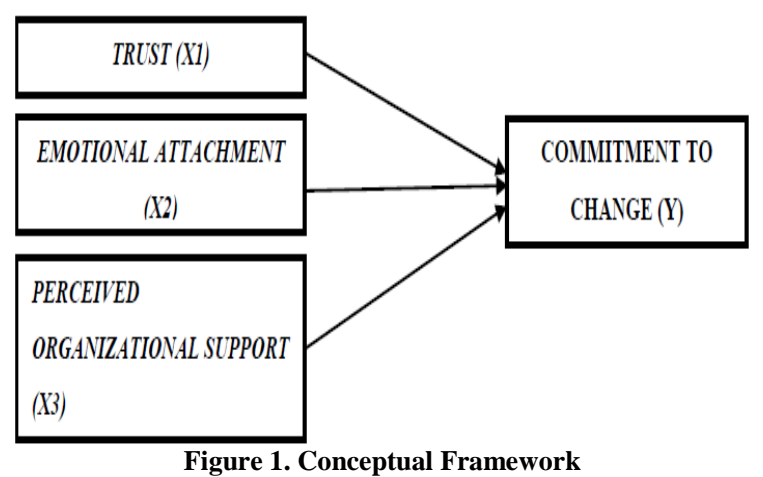

\section{Hypothesis}

1. There is a positive and significant relationship between trust and commitment to change and a negative and significant relationship between trust and resistance to change.

2. There is a positive and significant relationship between emotional attachment and commitment to change and a negative and significant relationship between emotional attachment and resistance to change.

3. There is a positive and significant relationship between perceived organizational support and commitment to change and a negative and significant relationship

\section{RESEARCH METHODS}

This type of research is descriptive statistical research. This study is intended to determine the factors that affect the commitment to change after reorganization, namely trust, emotional attachment and perceived organizational support at PT PLN (Persero) UIP Sumbagut. The population in this study were all employees at the PLN UIP Sumbagut unit, totaling 228 employees with a sample of 105 respondents. Questionnaires and interviews are ways to collect data by distributing a list of questions in order to obtain the information needed in a study. This study uses a quantitative analysis approach that adopts structural equation modeling-Partial Least Square (SEM-PLS) with analysis using SPSS software tools.

\section{RESULTS AND DISCUSSION Significance Test of Direct Effect (Direct Effect)}

Table 1. Path Coefficient Value and P-Value (Testing the Significance of Direct Influence)

\begin{tabular}{|c|c|c|c|c|c|}
\hline & $\begin{array}{l}\text { Original Sample } \\
\text { (O) }\end{array}$ & $\begin{array}{l}\text { Sample Mean } \\
\text { (M) }\end{array}$ & $\begin{array}{l}\text { Standard Deviation } \\
\text { (STDEV) }\end{array}$ & $\begin{array}{l}\text { T Statistics } \\
(|\mathrm{O} / \mathrm{STDEV}|) \\
\end{array}$ & P Values \\
\hline EA (X2) -> COMMITMENT (Y) & 0,277 & 0,267 & 0,115 & 2,407 & 0,016 \\
\hline POS (X3) -> COMMITMENT (Y) & 0,370 & 0,376 & 0,091 & 4,076 & 0,000 \\
\hline
\end{tabular}

1. EA (X2) has a positive effect on KUB (Y), with a path coefficient of 0.277 , and significant, with a P-Values value of $0.016<0.05$.

2. POS (X3) has a positive effect on KUB (Y), with a path coefficient of 0.370 , and significant, with a P-Values value of $0.000<0.05$.

3. TRUST (X1) has a positive effect on KUB (Y), with a path coefficient of 0.060 but not significant, with a PValues value of $0.637>0.05$.

\section{The coefficient of determination ( $r$ -} square).

Table 2. Value of the coefficient of determination

\begin{tabular}{|l|l|l|l|l|}
\hline F Square & $\begin{array}{l}\text { EA } \\
\text { (X2) }\end{array}$ & $\begin{array}{l}\text { KOMITMEN } \\
(\text { Y) }\end{array}$ & $\begin{array}{l}\text { POS } \\
\text { (X3) }\end{array}$ & $\begin{array}{l}\text { TRUST } \\
\text { (X1) }\end{array}$ \\
\hline EA (X2) & & 0,086 & & \\
\hline $\begin{array}{l}\text { COMMITMENT } \\
\text { (Y) }\end{array}$ & & & & \\
\hline POS (X3) & & 0,143 & & \\
\hline TRUST (X1) & & 0,004 & & \\
\hline
\end{tabular}

1. The coefficient of determination of TRUST (X1) is 0.004 . This value can be 
interpreted that TRUST (X1) is able to influence COMMITMENT (Y) by $0.4 \%$.

2. The coefficient of determination of EA (X2) is 0.086. This value can be interpreted that EA (Y2) is able to influence COMMITMENT (Y) by $86 \%$.

3. The coefficient of determination of POS (X3) is 0.143. This value can be interpreted that POS (X3) is able to affect COMMITMENT (Y) by $14.3 \%$.

\section{CONCLUSION}

1. The TRUST variable (X1) is able to directly influence the COMMITMENT variable $(\mathrm{Y})$ of $0.4 \%$, with a path coefficient of 0.060 but not significant, with a P-Values value of $0.637>0.05$.

2. The EA variable (Y2) is able to directly affect the COMMITMENT variable (Y) by $86 \%$, with a path coefficient value of 0.277 , and significant, with a P-Values value of $0.016<0.05$.

3. The POS variable (X3) is able to directly influence the COMMITMENT variable (Y) by $14.3 \%$, with a path coefficient value of 0.370 , and significant, with a P-Values value of $0.000<0.05$.

4. Employee Commitment to Change after reorganization is strongly influenced by Trust, Emotional Attachment and Perceived Organizational Support factors as part of organizational climate indicators that are very inherent in determining the success of reorganization.

\section{Acknowledgement: None}

\section{Conflict of Interest: None}

Source of Funding: None

\section{REFERENCES}

1. Desplaces, David., (2005), A Multilevel approach to individual readiness to change, Journal of Behavioral and Applied Management, Vol. 7 No.1, 25- 39.

2. Abrahamson, R. (2000). Organizational Cynicism: Bases and Consequences. Genetic, Social, and General Psychology Monographs, 126, 269- 292.

3. Kotter, John P., (2007, January), Leading Change: Why Transformation Effort Fail, Harvard Business Review, 1-10.

4. Holt, D. T. et. al. (2007). Readiness For Organizational Change : The Systematic Development Of A Scale. Journal of Applied Behavioral Science, 232-255.

5. Weiner, Bryan J., (2009). A theory of organizational readiness for change, Implementation Science, Vol. 4 No. 67.

6. Meyer, J.P., Stanley, D.J., Herscovitch, L., \& Topolnytsky, L. (2002). Affective, continuance and normative commitment to the organization: A meta- 54 analysis of antecedents, correlates and consequences. Journal of Vocational Behavior, 61, 20-52.

7. Rhoades, L. \& Eisenberger, R. 2002. Perceived Organizational Support: A Review of the Literature. Journal of Applied Psychology, 87(4): 698-714.

8. Rajiv R. Thakur. From resistance to readiness: the role of mediating variables; Bradford Vol. 31, Iss. 1, (2018).

9. Self, Dennis R. Organizational change overcoming resistance by creating readiness; Bradford Vol. 21, Iss. 5, (2007): 11-13.

10. McKay, Kali; Kuntz, Joana RC; Näswall, Katharina. The Effect of Affective Commitment, Communication and Participation on Resistance to Change: The Role of Change Readiness; Christchurch Vol. 42, Iss. 2, (2013): 29-40.

How to cite this article: Handayani RS, Sadalia I, Wibowo RP. The affecting factors of commitment to change after reorganization in PT PLN (Persero) UIP Sumbagut. International Journal of Research and Review. 2021; 8(4): 435-438. DOI: https://doi.org/10.52403/ijrr. 20210452 